\title{
Variability Studies in Local Rice Genotypes Using Agro-Morphological Characterization
}

\author{
Rohit Kumar* and Sonali Kar \\ Section of Genetics and Plant Breeding, Indira Gandhi Krishi Vishwavidyalaya, S.G. College \\ of Agriculture and Research Station, Jagdalpur- 494001, Chhattisgarh, India \\ *Corresponding author
}

Keywords

variability, local rice, genotypes and agro-morphological.

Article Info

Accepted:

22 December 2019

Available Online:

20 January 2020

\section{A B S T R A C T}

The present study was conducted at Research cum Instructional Farm, S.G. College of Agriculture and Research Station, Kumhrawand, Jagdalpur, Bastar, Chhattisgarh, India. One hundred and four rice genotypes lines were planted in three rows in two replication with four checks viz.,MTU 1010, Karma Masuri, Dub- raj Selection and HMTin Randomized Complete Block Design. Agro-morphological characters Plant height, Flag leaf length, Flag leaf width, Panicle length, grain yield per plant, number of panicles, Test weight, Days to $50 \%$ flowering, Days to harvesting days, Root length, Shoot length, Days to maturity, genotypes lines were found promising with respect to yield. One hundred and four rice germplasm lines were grouped into five clusters out of five clusters the cluster III constituted of 33 genotypes, forming the largest cluster. The estimates of heritability in broad sense andgenetic advance as percentage of mean were found high for trait gel consistency. Yield per plant was highly significantly and positively correlated with grain breadth, Volume expansion ratio, grain length breadth ratio, kernel breadth, days to maturity while significant negative correlated with days to $50 \%$ flowering and Shoot length.

\section{Introduction}

Rice is the world's most important staple food crop and is a primary food source for about half the world's population. It is cultivated in a wide range of ecosystem under varying climatic conditions. (Varietal improvement still remains the major strategy for increasing production). Also agronomic value of rice variety depends on many characteristics. The most important characteristics include Plant height, Flag leaf length, Flag leaf width, Panicle length, grain yield per plant, The number of panicles, Test weight, Days to $50 \%$ flowering, Days to harvesting, Root length, Shoot length, Days to maturity. Asian 
countries are the main rice producer, with its rice production accounting for nearly $92 \%$ of the world's total production It is cultivated in more than 112 countries. It has also been used as an important source of income and employment for rural masses as well as foreign exchange earning commodity and hence named "Golden Grain of Pakistan" (Ohtsubo et al., 2005).

In Bastar region of Chhattisgarh rice is grown predominantly during kharif season as rainfed crop having 2.39 million hectare area but the productivity of this crop is very low, 08.53 $\mathrm{qt} / \mathrm{ha}$. Rice based cropping systems are in existence and farmers raise traditional rice varieties and still adopt organic farming. Safari, Gurmatia, Sathka, BhataMokdo, ChudiDhan etc. are among these traditional varieties. According to the traditional healers of Bastar region many of these medicinal rice varieties are used in traditional medicine system for treatment of rheumatism, skin infections, paralysis, diabetes etc. (Oudhia, 2006).Chhattisgarh is traditionally known as the Rice Bowl of India. Over 20,000 rice varieties have been recorded in the region. These are a result of centuries of rice farming by indigenous communities through selection and adaptation to a variety of soil, water and micro-ecosystems conditions including predators. The Chhattisgarh region and adjoining area of Orissa are considered to be the store house of vast genetic variability and where varietal patterns change at every 250 hectaresof land due to extreme variation in the agro and eco-climate conditions, season, topography, altitude, soils, and moisture stress factors coupled with variation in the cultivars heritage of the inhabitant (Richhariya, 1979).

Characterized forty rice accessions using fourteen agro-botanical traits. Number of effective tillers and total number of tillers as well as heading and maturity dates were observed to greatly influence grain yield.
Significant block effects were observed for flowering date, maturity day and plant height whereas block effects were non-significant for the other traits meaning that blocking was not important for the eleven traits that showed non-significant block effects (Ogunbayo et al., 2005). Evaluated correlation between some traits and yield components of 6 aromatic rice varieties and also determined the most effective factors on its yield. Among 6 varieties Badshabhog was the top most yielder followed by Kataribhog, Chinigura, Radhunipagal, Begunbichi and Kalozira.

Analysis of variability parameters revealed that the phenotypic coefficients of variation were higher than genotypic coefficient of variation for all the characters studied. The spike lets per panicle and 1000 grain weight showed high heritability and effective tillers per hill showed low heritability. Yield has positive significant correlation with days to maturity, spikelet length and 1000-grain weight. Negative significant correlation was found with plant height and sterility $\%$ and non-significant correlation with other characters (Mishu et al., 2015)

\section{Materials and Methods}

The present study was conducted using around one hundred four local germplam of rice with four popular standard checks, MTU 1010, Karma Masuri, Dub- raj Selection and HMT. Raised nursery seed bed was prepared for placing of seeds. Nurseries were raised by taking seeds from single panicle in single row for each Genotype. Twenty three days old seedlings were subsequently transplanted in to the field in Randomized complete block design. The experimental material was planted in three rows in two replication with four checks. Spacing of $25 \mathrm{~cm}$ between rows and $15 \mathrm{~cm}$ between plants were kept. The checks varieties were randomized within block. Gap filling was done within a week in 
order to maintain uniform plant population. The NPK fertilizer was applied @ 120:60:60 $\mathrm{kg} / \mathrm{ha}$, respectively with full dose of $\mathrm{P}$ and $\mathrm{K}$ and $1 / 3^{\text {rd }}$ of as basal, $1 / 3$ rd of $\mathrm{N}$ at 30 DAT and remaining at 45 DAT. The standard agronomic practices were adopted for normal crop growth.

\section{Agronomical characters}

Rice accessions were evaluated for 12 agronomical traits viz, Plant height, Harvesting date, Days to $50 \%$ flowering, Panicle length, Flag leaf width, Flag leaf length, Days to Maturity, Number of effective tillers, Test weight, Grain yield per plant, root length, shoot length.

\section{Results and Discussion}

\section{Agronomical characters}

Table 1 revealed that most of the morphological characters showed variation in from five competitive plants of middle row of each entry. Plant height ranged from $80.01 \mathrm{~cm}$ (safedumari) to $132.50 \mathrm{~cm}$ (huldichudi) with a mean value of $104.73 \mathrm{~cm}$, flag leaf length ranged from $20.41 \mathrm{~cm}$ (Madraschudi) to 45.50 $\mathrm{cm}$ (Pakhiyadhan) with a mean value of 26.37 $\mathrm{cm}$,flag leaf width ranged from $0.94 \mathrm{~cm}$ (Kalakuriya) to $2.01 \mathrm{~cm}$ (Pankiguda) with a mean value of $1.55 \mathrm{~cm}$, Flag leaf length ranged from $20.41 \mathrm{~cm}$ (Madraschudi) to 45.50 $\mathrm{cm}$ (Pakhiyadhan) with a mean value of 26.37 $\mathrm{cm}$, flag leaf width ranged from $0.94 \mathrm{~cm}$ (Kalakuriya) to $2.01 \mathrm{~cm}$ (Pankiguda) with a mean value of $1.55 \mathrm{~cm}$, panicle length ranged from $7.15 \mathrm{~cm}$ (Bariyadhan) to $27.22 \mathrm{~cm}$ (Limchudi)with a mean value of $17 \mathrm{~cm}$, grain yield per plant varied from $16.15 \mathrm{~g}$ (Karigrass) to 32.25 g. (Karinarangis) with mean value of $21.28 \mathrm{~g}$, Effective no of tillers varied from 7.80(Ajamlali) to 15.40 . (Hathipanjro) with mean value of $10.48 \mathrm{~g}$, test weight ranged from $11.20 \mathrm{~g}$ (Thapaful) to
$30.70 \mathrm{~g}$ (Umaridhan) with an average of 21.12 , days to $50 \%$ flowering ranged from $80.00 \mathrm{~cm} \mathrm{(pandriluchai)} \mathrm{to} 122.00 \mathrm{~cm}$ (rangovati) with a mean value of 95.92 $\mathrm{cm}$, days to harvesting varied from lowest 114.50 days (Adgadhan) and highest 158 days (Kalamati) and their mean value is 144.15 days, root length ranged from $2.16 \mathrm{~cm}$ (Kusumjhopa) to $11.96 \mathrm{~cm}$ (Kata nakti) with a mean value of $6.56 \mathrm{~cm}$, shoot length ranged from $10.9 \mathrm{~cm}$ (Mayurfada) to $30.94 \mathrm{~cm}$ (Limchudi) with a mean value of 20.44 $\mathrm{cm}$,days to maturity ranged from 106 days (Pandriluchai) to 143 days (Rangovati, Huldichudi, Kalamati) with a mean value of 130.26 days.

Present finding are corroborate with Patil et al., (2009) who reported that genotypes exhibited significant variability in flag leaf length, plant height, panicle length. Kumar et al., (2015).studied in 25 rice hybrids and observed significant differences for thirteen yield contributing traits viz., plant height $(\mathrm{cm})$, flag leaf length $(\mathrm{cm}), 81$ flag leaf width (cm), number of panicles per hill, panicle length $(\mathrm{cm})$. This indicated the presence of substantial amount of genetic variability in the study material and there is ample scope for selection. Similarly, Ali et al., (2000) also observed relatively greater range in plant height than the other characters. Plant height in rice is a complex character and is the end product of several genetically controlled factors called internodes (Cheema et al., 1987). Some studies have reported on the considerable genetic variability that is available for producing differences in the morphological traits that govern root architecture, e.g., spatial configuration of the root system, number and length of laterals (Mouchel et al., 2004; Fitz Gerald et al., 2006).One important agronomic trait in the direct seeding is the long shoot length, because short shoots could not emerge from paddy water surface, which cause the seedling 
mortality (Peterson et al., 1978).

The estimates of heritability in broad sense were found high in days to maturity $(97.80 \%)$, days to $50 \%$ flowering $(96.26 \%)$, test weight (95.78\%), plant height $(92.41 \%)$, root length $(90.73 \%)$, days to harvesting $(90.17 \%)$. The estimates of heritability in broad sense were found moderate for yield per plant (75.38), shoot length $(73.12 \%)$.The estimates of heritabilityin broad sense were found low for panicle length (39.69\%),flag leaf length $(30.32 \%)$, effective number of tillers (27.29\%), flag leaf breadth $(22.51 \%)$.

Similarly results observed large amount of variability in 1000 seed weight, alkali spreading value, brown kernel L/B ratio and moderate variability in brown and cooked kernel length, amylose content and kernel elongation index. High heritability and genetic advance were noted for 1000 seed weight, amylose content, alkali spreading value and brown kernel $\mathrm{L} / \mathrm{B}$, implying the potential of these parameters to be used in breeding programme (Roy et al.2009). Studied variability and heritability for seven important physico-chemical traits viz., kernel length, kernel breadth, length/breadth ratio, kernel length after cooking, elongation ratio, alkali spreading value and amylose content. Low to moderate estimates of variability (both at genotypic and phenotypic level), moderate to high heritability and low expected genetic advance for all the characters indicated the preponderance of both additive and non-additive gene effects in conditioning these traits (Veni and Rani 2006).

Highest estimates of genetic advance as percentage of mean were observed for root length $(80.95 \%)$, yield per plant $(51.22 \%)$, test weight (46.07\%), shoot length (41.88\%). Moderate estimates of genetic advance as percentage of mean were observed for plant height $(25.66 \%)$. Low estimate of genetic advance as percentage of mean were observed for days to $50 \%$ flowering $(17.66 \%)$ followed by days to maturity (17.21\%), effective number of tillers $(14.06 \%)$, panicle length $(13.06 \%)$,days to harvesting $(11.71 \%)$ flag leaf length $(10.95 \%)$, and flag leaf breadth (7.01\%).

Yadav 2000, studied genetic variability in rice and observed appreciable amount of genotypic coefficient of variation, heritability and genetic advance for total grains per panicle, fertile grains per panicle and grain yield per plant. Selvaraj et al., 2011, reported that phenotypic coefficient of variation (PCV) values were slightly greater than genotypic coefficient of variation (GCV), revealing negligible influence of environment in character expression. Lingaiah et al., 2015 conducted experiment to estimate the genetic variability parameters for the quantitative characters in mid early group genotypes of rice cultivars. The analysis of variance revealed significant difference among the genotypes for the traits studied indicating that a large amount of variability was present in the material. The magnitude of phenotypic coefficient of variation was higher to genotypic co-efficient of variation for all the traits.

Yield per plant was highly significantly and positively correlated with grain breadth $(0.78 * *)$, Volume expansion ratio $(0.48 * *)$, grain length breadth ratio $(0.37 * *)$, kernel breadth $(0.22 * *)$, days to maturity $(0.20 * *)$. However significant negative correlated with days to $50 \%$ flowering(-0.26**)and Shoot length $\left(-0.26^{* *}\right)$ was observed.

Sarawagi et al., (1997), reported that biological yield per plant (0.7062)followed by harvest index (\%) (0.6794), panicle bearing tillers/plant, test weight (g) (0.4230), spikelet fertility $(\%)(0.4210)$ and spikelet/panicle (0.3775); w hile negative and significant correlation was observed with $\mathrm{L} / \mathrm{B}$ ratio and 
grain chalkiness. Agahi et al., (2007) estimated correlations among the traits to find out association and showed that the grain yield was significantly correlated with days to heading, total tillers, number of productive tillers, days to maturity, number of grains per panicle and plant height. Chakraborty et al., (2010), revealed significant positive correlation of grain yield per plant with plant height, number of panicles per plant, panicle length, number of filled grains per panicle and harvest index.

Table.1 List of one hundred and four local germplasm of rice with four popular standard checks used in the present study

\begin{tabular}{|c|c|c|c|}
\hline Entry No. & Genotype Name & Entry No. & Genotype Name \\
\hline 1 & Rangovati & 45 & Kabrodhan \\
\hline 2 & Jeeradhan & 46 & Badshabhog \\
\hline 3 & Pakhiyadhan & 47 & Masuridesi \\
\hline 4 & Masurdhan & 48 & Karmaribhog \\
\hline 5 & Kandai & 49 & Mokdodhan \\
\hline 6 & Mesodhan & 50 & Sonasari \\
\hline 7 & Lodhiyari & 51 & Bhaiyakhuta \\
\hline 8 & Jhodranakti & 52 & Ganga baru \\
\hline 9 & Loktimachhi & 53 & Kurlukabri \\
\hline 10 & Pandariluchai & 54 & Huldigadi \\
\hline 11 & Kusumjhopa & 55 & Huldichudi \\
\hline 12 & Pandarisatka & 56 & Sargiful \\
\hline 13 & Motilure & 57 & Kursobhog \\
\hline 14 & Chairadhan & 58 & Muthiya \\
\hline 15 & Kala umari & 59 & Mayufada \\
\hline 16 & Baghelbijo & 60 & Olesar \\
\hline 17 & Kata barangi & 61 & Milkormel \\
\hline 18 & Umaridhan & 62 & Baundri \\
\hline 19 & Hardiful & 63 & Kumhadaful \\
\hline 20 & Farsaful & 64 & Aajamlali \\
\hline 21 & Ram laxman & 65 & Gogal \\
\hline 22 & Dumarful & 66 & Madraschudi \\
\hline 23 & Sendursenga & 67 & Jhumradhan \\
\hline
\end{tabular}




\begin{tabular}{|c|c|c|c|}
\hline 24 & Tikichudi & 68 & Kanidhan \\
\hline 25 & Bhatakandai & 69 & Faradhan \\
\hline 26 & Gadakhuta & 70 & Degichudi \\
\hline 27 & Goyadi & 71 & Katakdhan \\
\hline 28 & Kata nakti & 72 & Garegadhan \\
\hline 29 & Bhatamokdo & 73 & Halkalalsatka \\
\hline 30 & Kukdamudi & 74 & Kasi Kaman \\
\hline 31 & Haldighati & 75 & Thapaful \\
\hline 32 & Tama koni & 76 & Kala kuriya \\
\hline 33 & Nanichudi & 77 & Parvatibhog \\
\hline 34 & Kalmati & 78 & Borgum \\
\hline 35 & Mohadhan & 79 & Asamiyadhan \\
\hline 36 & Kari narangi & 80 & Limchudi \\
\hline 37 & Dandkar & 81 & Karigrass \\
\hline 38 & Bhaispat & 82 & Bhyardhan \\
\hline 39 & Keraful & 83 & Chatiyadhan \\
\hline 40 & Dhotiyadhan & 84 & Luchaidhan \\
\hline 41 & Gadursela & 85 & Dokramecha \\
\hline 42 & Altimijo & 86 & Kata mehr \\
\hline 43 & Safedumari & 87 & Bariyadhaan \\
\hline 44 & hadhardhan & 88 & Hathipanjaro \\
\hline 89 & Cheptikhuji & 97 & Baiganidhaan \\
\hline 90 & Rambhog & 98 & Pankiguda \\
\hline 91 & HiranBako & 99 & Dongarkabri \\
\hline 92 & Surmutiya & 100 & Kharlamahu \\
\hline 93 & Chindjhopa & 101 & TemruMudi \\
\hline 94 & Baktichudi & 102 & Hansadubraj \\
\hline 95 & Adgadhan & 103 & Lakhechi \\
\hline 96 & Aajandhaan & 104 & Shivnath \\
\hline
\end{tabular}

CH1 MTU 1010, CH2 Karma Masuri, CH3 Dubraj Selection, CH4 HMT. Note: CH=check variety. 
Table.2 Mean, Range, coefficient of variation \% (CV \%), Heritability (h2), and genetic advance as per cent of mean (GA as \% of mean) for different characters.

\begin{tabular}{|c|l|l|l|l|l|l|l|l|}
\hline S.N. & Traits & Mean & Range & Maxi. & Mini. & CV\% & $\begin{array}{l}\text { h2 (BS) } \\
\text { \% GA }\end{array}$ & $\begin{array}{l}\text { GA as \% of } \\
\text { Mean }\end{array}$ \\
\hline $\mathbf{1}$ & PH $(\mathrm{cm})$ & $104.73 \pm 1.07$ & 72.29 & 132.50 & 80.01 & 2.94 & 92.41 & 25.66 \\
\hline $\mathbf{2}$ & FLL (cm) & $26.37 \pm 0.29$ & 25.09 & 45.50 & 20.41 & 11.59 & 30.32 & 10.95 \\
\hline $\mathbf{3}$ & FLW (cm) & $1.55 \pm 0.01$ & 1.07 & 2.01 & 0.94 & 10.54 & 22.51 & 7.013 \\
\hline $\mathbf{4}$ & PL (cm) & $17.28 \pm 0.22$ & 16.10 & 27.22 & 7.15 & 9.89 & 39.69 & 13.06 \\
\hline $\mathbf{5}$ & PPY (cm) & $21.28 \pm 0.5$ & 16.1 & 57.07 & 10.38 & 12.96 & 75.38 & 51.22 \\
\hline $\mathbf{6}$ & ENT & $10.48 \pm 0.16$ & 7.60 & 32.25 & 16.15 & 16.89 & 27.29 & 14.06 \\
\hline $\mathbf{7}$ & TW (g) & $21.12 \pm 0.47$ & 19.50 & 30.70 & 11.20 & 3.79 & 95.78 & 46.07 \\
\hline $\mathbf{9}$ & HD & 144.1538 & 43.50 & 158.00 & 114.50 & 1.56 & 90.17 & 11.71 \\
\hline $\mathbf{1 0}$ & RL (cm) & $6.56 \pm 0.22$ & 9.80 & 11.96 & 2.16 & 10.44 & 90.73 & 80.95 \\
\hline $\mathbf{1 1}$ & SL (cm) & $20.44 \pm 0.4$ & 20.04 & 30.94 & 10.9 & 11.42 & 73.12 & 41.88 \\
\hline $\mathbf{1 2}$ & MD & 130.2692308 & 37.00 & 143.00 & 106 & 1.00 & 97.80 & 17.21 \\
\hline
\end{tabular}

PH: Plant height $(\mathrm{cm})$, FLL: Flag leaf length $(\mathrm{cm})$, FLW: Flag leaf width $(\mathrm{cm})$, PL: Panicle length $(\mathrm{cm})$, PPY: Yield Per plant (g), ENT: Effective no of tillers, TW: Test weight(g,) DTF: Days of 50\% flowering, HD: Harvesting date, RL: Root length(cm), SL: Shoot length(cm), MD: Maturity date.

Table.3 Genotypic correlation coefficient for quantitative traits

\begin{tabular}{|c|c|c|c|c|c|c|c|c|c|c|c|}
\hline characters & $\mathbf{P H}$ & FLL & FLB & PL & PPY & ENT & TW & DLF & RL & SL & MD \\
\hline $\mathbf{P H}$ & 1 & -0.019 & -0.001 & 0.121 & $0.254 * *$ & $0.142 *$ & $0.637 * *$ & $-0.198 * *$ & 0.042 & $0.412 * *$ & $-0.580 * *$ \\
\hline FLL & & & -0.128 & -0.092 & 0.024 & $0.151^{*}$ & 0.078 & $-0.188 * *$ & $0.785^{* *}$ & $-0.492 * *$ & $0.190 * *$ \\
\hline FLB & & & & $0.281 * *$ & -0.078 & $0.751 * *$ & $0.176^{*}$ & -0.088 & $-0.164 *$ & $0.644 * *$ & $0.750 * *$ \\
\hline PL & & & & & -0.127 & $-0.139 *$ & $0.868 * *$ & $-0.160 *$ & $-0.143^{*}$ & $-0.329 * *$ & $-0.324 * *$ \\
\hline PPY & & & & & & -0.027 & 0.042 & $-0.268 * *$ & 0.024 & $-0.263 * *$ & $0.203 * *$ \\
\hline ENT & & & & & & & -0.027 & 0.025 & -0.133 & -0.110 & $0.148^{*}$ \\
\hline TW & & & & & & & & 0.063 & $-0.229 * *$ & $-0.305^{* *}$ & 0.103 \\
\hline DLF & & & & & & & & & 0.108 & $-0.343 * *$ & 0.132 \\
\hline HD & & & & & & & & & -0.031 & 0.002 & $0.205^{* *}$ \\
\hline RL & & & & & & & & & & $-0.141 *$ & 0.094 \\
\hline SL & & & & & & & & & & & -0.010 \\
\hline MD & & & & & & & & & & & \\
\hline
\end{tabular}

PH: Plant height $(\mathrm{cm})$, FLL: Flag leaf length $(\mathrm{cm})$, FLW: Flag leaf breadth $(\mathrm{cm})$, PL: Panicle length $(\mathrm{cm})$, PPY:

Yield Per plant (g), ENT: Effective no of tillers, TW: Test weight (g,), Days of 50\% flowering, HD: Harvesting date,

RL: Root length $(\mathrm{cm})$, SL: Shoot length $(\mathrm{cm})$, MD: Maturity date 


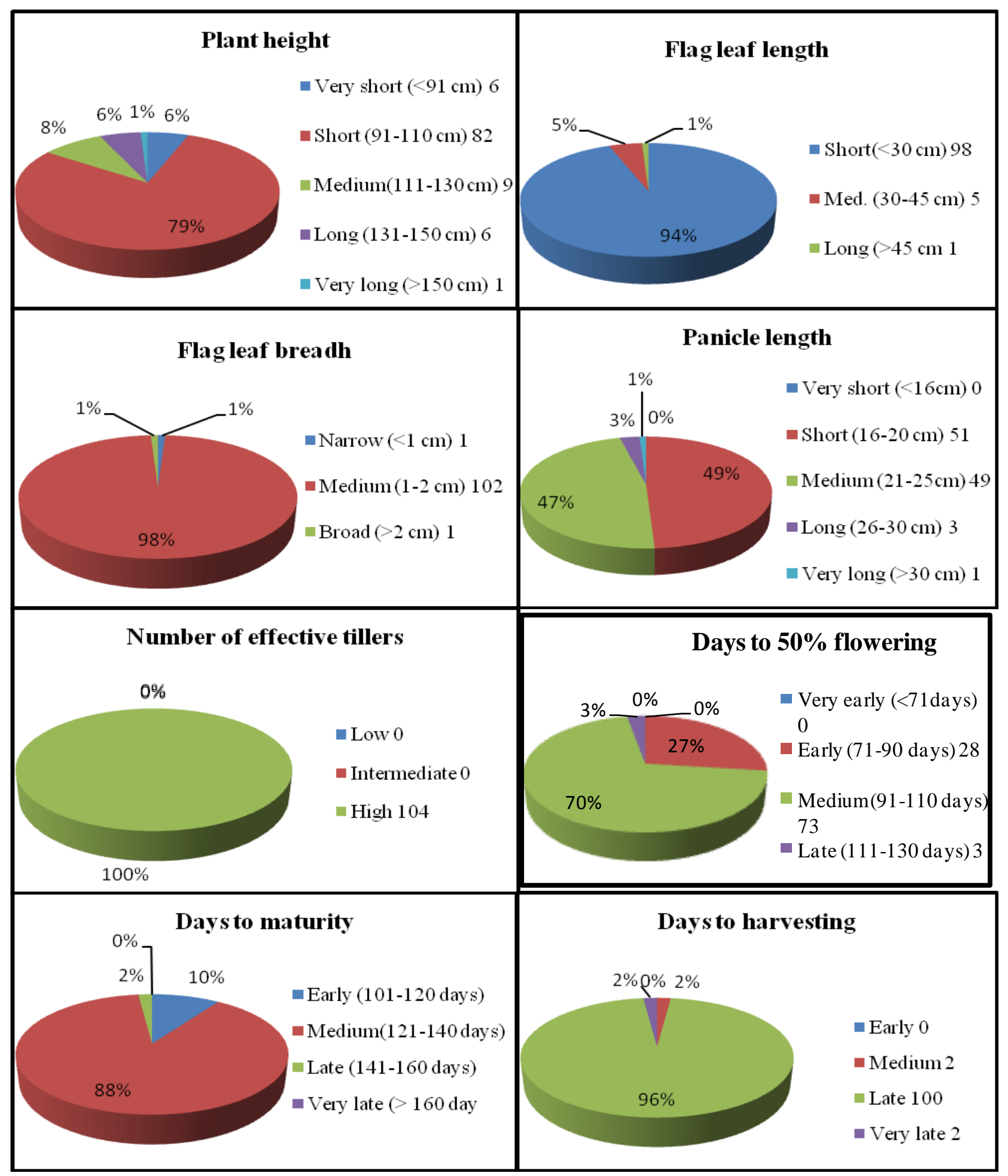

Fig.1 Frequency distribution of important morphological characters 
Table.4 Phenotypic Correlation for quantitative traits

\begin{tabular}{|l|l|l|l|l|l|l|l|l|l|l|l|l|}
\hline characters & PH & FLL & FLB & PL & PPY & ENT & TW & DLF & RL & SL & MD & (2) \\
\hline PH & & -0.015 & -0.002 & 0.104 & $0.223^{* *}$ & 0.125 & $0.588^{* *}$ & $-0.189^{* *}$ & 0.040 & $0.401^{* *}$ & $-0.597^{* *}$ \\
\hline FLL & & & -0.074 & -0.080 & 0.022 & 0.120 & 0.073 & $-0.178^{*}$ & $0.773^{* *}$ & $-0.473^{* *}$ & $0.181^{* *}$ \\
\hline FLB & & & & 0.060 & -0.074 & $0.718^{* *}$ & $0.147^{*}$ & -0.084 & $-0.158^{*}$ & $0.625^{* *}$ & $0.708^{* *}$ \\
\hline PL & & & & & -0.075 & -0.131 & $0.841^{* *}$ & -0.117 & -0.135 & $-0.311^{* *}$ & $-0.315^{* *}$ \\
\hline PPY & & & & & & -0.013 & 0.042 & $-0.258^{* *}$ & 0.023 & $-0.245^{* *}$ & $0.185^{* *}$ \\
\hline ENT & & & & & & & 0.006 & 0.024 & -0.108 & -0.097 & 0.134 \\
\hline TW & & & & & & & & 0.047 & $-0.225^{* *}$ & $-0.257^{* *}$ & 0.083 \\
\hline DLF & & & & & & & & & 0.107 & $-0.332^{* *}$ & 0.107 \\
\hline HD & & & & & & & & & -0.015 & 0.003 & $0.194^{* *}$ \\
\hline RL & & & & & & & & & & -0.092 & 0.091 \\
\hline SL & & & & & & & & & & & 0.001 \\
\hline MD & & & & & & & & & & & \\
\hline
\end{tabular}

PH: Plant height $(\mathrm{cm})$, FLL: Flag leaf length $(\mathrm{cm})$, FLW: Flag leaf breadth $(\mathrm{cm})$, PL: Panicle length $(\mathrm{cm})$, PPY:

Yield Per plant (g), ENT: Effective no of tillers, TW: Test weight (g,), Days of 50\% flowering, HD: Harvesting date, RL: Root length (cm), SL: Shoot length(cm), MD: Maturity date,

\section{References}

Agahi, K., Fotokian, M.H. and Farshadfar, E. 2007. Correlation and path analysis of some yield related traits in rice genotypes (Oryzasativa L.). Asian Journal of Plant Science. 6(3): 513-517.

Ali, S.S., Jafri, S.J.H., Khan, T.Z., Mahmood, A. and Butt, M.A. 2000. Heritability of yield and yield components of rice. Pakistan Journal of Agricultural Research, 16: 89-91.

Chakraborty, S., Das, P.K., Guha, B., Sarmah, K.K. and Barman, B. 2010. Quantitative genetic analysis for yield and yield components in boro rice (Oryzasativa L.). Notulae Science Biologicae, 2(1): 117-120.

Cheema, A.A., Awan, M.A. and Iqbal, J. 1987. Improvement of plant height architecture in basmati rice. Pakistan Journal of Agricultural Research, 8: 371-401

Fitz Gerald JN, Lehti-Shiu MD, Ingram PA, Deak KI, Biesiada T, Malamy JE (2006) Identification of quantitative trait loci that regulate Arabidopsis root system size and plasticity, Genetics 172:485498.

Kumar, N. Tiwari, B. Lal, G.M., Mishra, S.P., Katiyar, A. and Khuntey, Y. 2015. Evaluation of rice hybrids (OryzasativaL.) for yield and its component characters. Indian Research Journal Genetics \& Biotechnology, 7(1): 41-43.

Lingaiah, N. 2015. Genetic variability, heritability and genetic advance in rice (Oryzasativa L.). Asian Journal of Environmental Science, 10(1): 110-112. Mishu, M.F.K., Rahman, M.D.W., Azad, Md. A. K., Biswas, B. K., Talukder, Md. A.I., Kayess, Md. O., Islam, Md. R. and Alam, Md. R. 2015. Study on Genetic Variability and Character Association of Aromatic Rice (OryzasativaL.) Cultivars. International Journal of Plant \& Soil Science, 9(1): 18.

Mouchel, C.F., Briggs, G.C., Hardtke, C.S. 2004. Natural genetic variation in Arabidopsis identifies BREVIS RADIX, a novel regulator of cell 
proliferation and elongation in the root, Genes Dev 18: 700-714.

Oudhia, P., (2006): Chhui-Mui or Lajwanti (Mimosa pudica Linn.). Available from:http://www.hort.purdue.edu/newc orp/corpFactSheets/mimosa.html.Acces sed on 15.9.2008.

Patil, S.G., Sahu, V.N., Deokar, P.A., 2009. Study of variability of rice germplasm accessions used for wild rice eradication. International Journal of Plant Sciences, Muzaffarnagar, 4 (2): 535-537.

Peterson, M.L., Jones, D.B. and Rutger, J.N. 1978. Cool temperature screening of rice lines for seedling vigor, Il Riso 27 : 269-274.

Richharia, R.H. 1979. An aspect of genetic diversity in rice.Oryza, 16(1): 1-31.

Roy, S., Banerjee, A and Senapati, B.K. 2009.Evaluation of some aromatic rice germplasm in new alluvial soil of West Bengal. Environment and Ecology, 27
(3): $1240-1242$.

Sarawgi, A.K., Rastogi, N.K., Soni, D.K. 1997. Correlation and path analysis in rice accessions from Madhya Pradesh. Field Crops Research, 52(1-2):161-167.

Selvaraj, L., Nagrajan, P., Thiyagrajan, K. Bharathi, M. and Rabindra, R. 2011.Genetic Parameters of variability, correlation and path coefficient studies for grain yield and other yield attributes among rice blast resistant genotypes of rice (OryzaSativa L.). African Journal of biotechnology, 10(17): 3322-3334.

Veni, B.K. and Rani, N.S. 2006. Association of grain yield with quality characteristics and other yield components in rice, Oryza., 43: 320322.

Yadav, R.K. 2000.Studies on genetic variability for some quantitative characters in rice.Advances in Agricltural Research. 13: 205-207.

\section{How to cite this article:}

Rohit Kumar and SonaliKar. 2020. Variability Studies in Local Rice Genotypes Using AgroMorphological Characterization. Int.J.Curr.Microbiol.App.Sci. 9(01): 2397-2406. doi: https://doi.org/10.20546/ijcmas.2020.901.273 